\title{
CONTROL TECHNOLOGY AND EXPOSURE ASSESSMENT FOR OCCUPATIONAL EXPOSURE TO BERYLLIUM: ABRASIVE BLASTING WITH COAL-SLAG
}

\author{
PRINCIPAL AUTHORS: \\ Keith G. Crouch \\ Alan S. Echt \\ Robert Kurimo \\ Yvonne T. Gagnon
}

REPORT DATE:

August, 2007

FILE NO.:

EPHB 263-13a

\section{U.S. DEPARTMENT OF HEALTH AND HUMAN SERVICES}

Centers for Disease Control and Prevention

National Institute for Occupational Safety and Health

Division of Applied Research and Technology

4676 Columbia Parkway, R5

Cincinnati, Ohio 45226 
SITES SURVEYED:

SIC CODE:

SURVEY DATE:

SURVEY CONDUCTED BY:

EMPLOYEE REPRESENTATIVES:

EMPLOYER REPRESENTATIVE

CONTACTED:
Annapolis Water Reclamation Facility, Annapolis, MD

1721 Engineering structure (e.g., oil storage tank, water tower) painting

June 21-23, 2004

Keith Crouch

Alan Echt

Robert Kurimo

Yvonne Gagnon

International Union of Painters and

Allied Trades District Council 21

- Local 703 Blaster

- Local 997 Helper

C. William Etzler

Construction Manager

Construction Dynamics Group 


\section{DISCLAIMER}

Mention of company names or products does not constitute endorsement by the Centers for Disease Control and Prevention.

The findings and conclusions in this report are those of the author(s) and do not necessarily reflect the views of the National Institute for Occupational Safety and Health. 


\section{INTRODUCTION}

The National Institute for Occupational Safety and Health (NIOSH), working under an interagency agreement with the Office of Regulatory Analysis of the Occupational Safety and Health Administration (OSHA), conducted a study to survey occupational exposures to beryllium and to document engineering controls and work practices affecting those exposures. The performance of a thorough industrial hygiene survey for a variety of individual employers provides valuable and useful information to the public and employers in the industries included in the work. The principal objectives of this study were:

1. To identify and describe the control technology and work practices in use in operations associated with occupational exposures to beryllium, as well to determine additional controls, work practices, substitute materials, or technology that can further reduce occupational beryllium exposures.

2. To measure full-shift, personal breathing zone, particulate exposures to beryllium. These samples provide examples of exposures to beryllium among workers across the many industries where beryllium is encountered. These exposure data, along with the control data described above, provide a picture of the conditions in the selected industries.

This site visit was conducted on June 21-23, 2004, by NIOSH researchers from the Engineering and Physical Hazards Branch, Division of Applied Research and Technology, in Cincinnati, Ohio.

Occupational exposure to beryllium occurs at places where the chemical is mined, processed, or converted into metal, alloys, and other chemicals. Workers engaged in machining metals containing beryllium, recycling beryllium from scrap alloys, or using beryllium products may also be exposed to higher levels of beryllium. The number of workers exposed to beryllium or beryllium compounds has been estimated to be 21,000 (ATSDR 2002). There is a need to understand the nature of these beryllium exposures, what is causing the exposures, and what steps are being taken or could be taken to reduce the exposures (e.g., engineering controls, work practices, and personal protective equipment).

Beryllium has been reported in mineral slag abrasives, including coal slag (Stettler et al. 1982, NIOSH 1998, Meeker et al. 2006). Stettler et al (1982) reported the results of the analysis of 12 coal slags; 9 contained beryllium, ranging from 7-48 micrograms per gram $(\mu \mathrm{g} / \mathrm{g})$. Meeker et al. (2006) found beryllium in clean coal slag samples, and found task-weighted personal exposures outside of the blasters' personal protective equipment that ranged from 2.5-9.5 micrograms of beryllium per cubic meter of air $\left(\mu \mathrm{g} / \mathrm{m}^{3}\right)$. They reported a geometric mean beryllium exposure of $5 \mu \mathrm{g} / \mathrm{m}^{3}$. NIOSH (1998) evaluated coal slags (including Black Beauty ${ }^{\mathrm{TM}}$ ) with and without the addition of a dust suppressant compound and reported a geometric mean airborne concentration of 2.040 milligrams $(\mathrm{mg}) / \mathrm{m}^{3}$ for the entire coal slag category tested. 
The OSHA general industry standard sets a permissible exposure limit (PEL) at $2 \mu \mathrm{g} / \mathrm{m}^{3}$ for an 8-hour time-weighted average (TWA), or $5 \mu \mathrm{g} / \mathrm{m}^{3}$ of beryllium in air, not to exceed 30 minutes at a time (29 CFR 1910.1000). OSHA also requires that workers in general industry should never be exposed to more than $25 \mu \mathrm{g} / \mathrm{m}^{3}$ of beryllium in air, regardless of how short the exposure. The OSHA PEL for the construction industry for beryllium and beryllium compounds (as $\mathrm{Be})$ is $0.002 \mathrm{mg} / \mathrm{m}^{3}\left(2 \mu \mathrm{g} / \mathrm{m}^{3}\right)$ as an 8-hour TWA (29 CFR 1926.55). The current NIOSH Recommended Exposure Limit (REL) for beryllium is $0.5 \mu \mathrm{g} / \mathrm{m}^{3}$, while the current American Conference of Governmental Industrial Hygienists $\left(\mathrm{ACGIH}^{\circledR}\right)$ Threshold Limit Value $\left(\mathrm{TLV}^{\circledR}\right)$ is an 8-hr TWA of $2 \mu \mathrm{g} / \mathrm{m}^{3}$, and a Short Term Exposure Limit (STEL) of $10 \mu \mathrm{g} / \mathrm{m}^{3}$ (NIOSH 1997 , ACGIH 2001). The OSHA PEL for the construction industry for particulates not otherwise regulated, total dust organic and inorganic is $15 \mathrm{mg} / \mathrm{m}^{3}, 8$-hour TWA (29 CFR 1926.55).

Surface sampling is not appropriate for estimating exposures but is useful for evaluating process control and cleanliness and for determining suitability for release of equipment. There are no surface contamination regulations applicable to the use of beryllium in general industry or construction. However, a useful guideline is provided by the U.S. Department of Energy (DOE), where DOE and its contractors are required to conduct routine surface sampling to determine housekeeping conditions wherever beryllium is present in operational areas of DOE/NNSA facilities (10 CFR 850). Those facilities must maintain removable surface contamination levels that do not exceed $3 \mu \mathrm{g} / 100 \mathrm{~cm}^{2}$ during non-operational periods (10 CFR 850). The DOE also has release criteria that must be met before beryllium-contaminated equipment or other items can be released to the general public or released for use in a non-beryllium area of a DOE facility. These criteria state that the removable contamination level of equipment or item surfaces does not exceed the higher of $0.2 \mu \mathrm{g} / 100 \mathrm{~cm}^{2}$ or the level of beryllium in the soil in the area of release. Removable contamination is defined as "beryllium contamination that can be removed from surfaces by nondestructive means, such as casual contact, wiping, brushing, or washing" (10 CFR 850). 


\section{METHODS}

This field study was conducted in accordance with 42 CFR 85a, the NIOSH regulations governing the investigation of places of employment (42 CFR 85a). The first day at the site was spent meeting with company personnel (company management, employees) to arrange sampling on the subsequent days, and to walk through the work site to begin the industrial hygiene assessment of exposure and control technology. Prior to sampling, the workers (2) were briefed on the sampling procedures to be conducted.

Personal breathing zone and general area particulate samples were collected and analyzed for beryllium. Particulate samples were collected at a flow rate of 1 liter/minute using a calibrated battery-powered sampling pump (model 224, SKC Inc., Eighty Four, PA) connected via flexible tubing to a 37-mm diameter, $0.8 \mu \mathrm{m}$ pore-size mixed cellulose ester filter in a 3-piece, clear plastic cassette sealed with a cellulose shrink band.

Gravimetric analysis for total particulate collected on personal breathing zone and general area filter samples was carried out with the following modifications to NIOSH Method 0500: 1) the filters and backup pads were stored in an environmentally controlled room $\left(20 \pm 1{ }^{\circ} \mathrm{C}\right.$ and $50 \pm 5 \%$ relative humidity) and were subjected to the room conditions for at least two hours for stabilization prior to tare and gross weighing, and, 2) two weighings of the tare weight and gross weight were performed. NIOSH Method 0500 recommends that the user equilibrate the filters in an environmentally controlled weighing area while the modification gives the specific temperature and humidity. The second weighing was added for precision and accuracy control. The difference between the average gross weight and the average tare weight was the result of the analysis. The limit of detection (LOD) for this method was $0.02 \mathrm{mg}$.

The total particulate samples were then analyzed for beryllium using inductively coupled plasma spectroscopy (ICP) according to NIOSH Method 7300 (NIOSH 1994) with modifications. Each filter was transferred to a clean $250 \mathrm{~mL}$ Phillips beaker. Next, $4 \mathrm{~mL}$ of concentrated nitric acid and $1 \mathrm{~mL}$ of perchloric acid were added to each sample. The beakers were then covered with watch glasses and the samples were allowed to react. The samples were then placed on a hotplate and allowed to reflux and reduce to approximately $0.5 \mathrm{~mL}$. Following reduction, additional aliquots of nitric acid and perchloric acid were added two more times. The samples were heated again and refluxed and reduced to approximately $0.5 \mathrm{~mL}$, when they were removed from the hotplate. After cooling, $2 \mathrm{~mL}$ of concentrated nitric acid was added to each beaker. The samples were then transferred to $25 \mathrm{~mL}$ volumetric flasks and diluted to volume with ASTM Type II water. The samples were shaken and transferred to clean vials. The LOD for beryllium with this method was $0.005 \mu \mathrm{g} / \mathrm{sample}$. The limit of quantitation (LOQ) was $0.02 \mu \mathrm{g}$ of beryllium per sample. Results between the LOD and LOQ are semi-quantitative.

Surface wipe samples were collected using Ghost Wipe ${ }^{\mathrm{TM}}$ sampling wipes (Environmental Express, Mt. Pleasant, SC) in accordance with ASTM Method D 6966-03, except that the template was held in place, rather than taped in place, to prevent movement during sampling 
(ASTM 2003). The samples were digested and analyzed according to NIOSH Method 7303 (NIOSH 1994) modified for hot-block digestion. The wipes were placed in $50 \mathrm{~mL}$ polypropylene centrifuge tubes with $10 \mathrm{~mL}$ of $1: 1$ nitric acid:ASTM Type II water. The samples were allowed to sit overnight. The samples were digested in a hotblock for one hour at $110^{\circ} \mathrm{C}$. The digestates were then brought to a final volume of $25 \mathrm{~mL}$ with ASTM Type II water and analyzed by ICP. The LOD for this method is $0.01 \mu \mathrm{g}$ of beryllium per sample. The LOQ is $0.03 \mu \mathrm{g} / \mathrm{sample}$.

In the case of beryllium-containing aerosol, there is substantial evidence that the presence of an ultrafine component increases the toxicity for chronic beryllium disease, so knowledge of the aerosol size distribution can help in evaluation of the health hazard. Personal breathing zone and general area aerosol size distributions were determined using a four-stage impactor, a Sioutas Cascade Impactor (SKC, Inc., Eighty Four, PA), having nominal 50\% cut points of 0.25, 0.5, 1, and 2.5 microns aerodynamic diameter. The sampling flow rate for this impactor was 9 liters/minute, provided by a calibrated Leland Legacy ${ }^{\mathrm{TM}}$ sampling pump (SKC, Inc., Eighty Four, PA). A $25 \mathrm{~mm}$ diameter, $0.8 \mu \mathrm{m}$ pore size $\mathrm{PVC}$ filter was used on each stage of the impactor to collect particles. A $37 \mathrm{~mm}$ diameter, $5 \mu \mathrm{m}$ pore size PVC filter was used as a backup to collect all particles that were not impacted on the previous four stages. The mass collected on each stage and backup filter was determined by NIOSH Method 0500 with the following modifications: 1) The filters were stored in an environmentally controlled room $\left(20^{\circ} \pm 1^{\circ} \mathrm{C}\right.$ and $50 \pm 5 \%$ R.H.) and were subjected to the room conditions for at least two hours for stabilization prior to tare and gross weighing; and 2) Two weighings of the tare weight and the gross weight were performed. The averages of the weighings were used for the total weight analysis. The LOD for the mass loading per filter was $0.02 \mathrm{mg}$. Because of the nature of the abrasive blasting process, some loose particles were found on some stages of impactors. These particles were weighed and reported separately from the filter-deposited mass, when they appeared to be generally larger than expected for the stage where they were found. Otherwise, the mass of the loose particles was added to the reported total for the stage where they were found.

After the impactor filters were weighed, they were then analyzed by ICP in accordance with NIOSH Method 7300 modified for microwave digestion (NIOSH 1994). The filters were digested in a CEM MARS 5 microwave in the presence of $10 \mathrm{~mL}$ of concentrated nitric acid and $2 \mathrm{~mL}$ of ASTM Type II water. After digestion, the samples were allowed to cool and diluted to $50 \mathrm{~mL}$ final volume with ASTM Type II water in $50 \mathrm{~mL}$ centrifuge tubes. The LOD for beryllium was $0.01 \mu \mathrm{g} / \mathrm{sample}$. The LOQ was $0.04 \mu \mathrm{g} / \mathrm{sample}$. Results between the LOD and LOQ are semi-quantitative.

Finally, three bulk samples were collected and analyzed for beryllium using NIOSH Method 7300 (NIOSH 1994), modified for bulk digestion as follows: A $0.25 \mathrm{~g}( \pm 0.005 \mathrm{~g})$ aliquot of sample was weighed out and placed in a $50 \mathrm{~mL}$ polypropylene centrifuge tube with $10 \mathrm{~mL}$ of concentrated nitric acid. The sample was digested in a hotblock for one hour at $110^{\circ} \mathrm{C}$. The digestate was then brought to the final volume of $50 \mathrm{~mL}$ with ASTM Type II water. The LOD for beryllium was $0.05 \mu \mathrm{g} / \mathrm{g}$. The LOQ was $0.2 \mu \mathrm{g} / \mathrm{g}$. Two of the bulk samples were collected 
directly from one shipping bag. The third was taken from the floor of the tank near the abrasive blasting site, was considered representative of the larger particles of spent abrasive, and contained material removed from the surfaces being cleaned.

During the site visit, information pertinent to process operation and control effectiveness (e.g. control methods, ventilation rates, work practices, use of personal protective equipment, etc.) was also collected. A thorough description of the process is essential to understanding the role of engineering controls and work practices. The work practices and use of personal protective equipment were also recorded for the workers. Information was obtained from conversations with the workers to determine if the sampling day was a typical work day. This information helped place the sampling results in proper perspective. The summary of engineering control information includes such items as ventilation flow rates and distance measurements.

NIOSH researchers calculated the exposures from the analytical results after correcting for the results of field blanks. For the employees sampled, an eight-hour time weighted average (TWA) exposure to beryllium was calculated. The TWA was calculated assuming that no additional beryllium exposure occurred during the unsampled period. For the samples that were below the LOD, an LOD-derived concentration $(\mathrm{LOD} / \sqrt{ } 2)$ was used to calculate the TWA (Hornung and Reed 1990). 


\section{PROCESS DESCRIPTION AND CONTROL TECHNOLOGY}

On June 21-23, 2004, research personnel from NIOSH conducted a site visit at the Annapolis Water Reclamation Facility in Annapolis, MD. The purpose of the study was to identify and describe the control technology and work practices in use during abrasive blasting operations in Secondary Clarifier No. 2, and measure beryllium exposures associated with the use of Black Beauty ${ }^{\mathrm{TM}}$ coal slag abrasive. Published reports indicate that coal slag abrasives, such as Black Beauty $^{\text {TM }}$, contain beryllium (Stettler et al. 1982, NIOSH 1998, Meeker et al. 2006).

\section{Process Description and Work Practices}

Abrasive blasting was conducted inside Secondary Clarifier no. 2, an empty open-top, in-ground circular vessel 110 feet in diameter and approximately 10 feet deep. The abrasive media, Black Beauty ${ }^{\mathrm{TM}}$ brand coal slag abrasive, was supplied in 100 pound bags. A helper loaded bags by hand into a blast pot with a capacity of 500 pounds. Compressed air was supplied by an Ingersoll Rand model P375 WJD compressor. The nozzle holder was a Clemco 0578 holder. The nozzle was a number 5 nozzle stamped 10TC5BP. The new steel on the side of the tank was being cleaned of mill scale down to white metal in preparation for painting, part of a tank renovation project.

\section{Personal Protective Equipment}

The blaster wore steel-toed shoes, cloth coveralls, leather blasting gloves and a Bullard type CE air-supplied respirator ( 88 series, Bullard, Cynthiana, Kentucky). See Figure 1. Air was supplied to the respirator from a compressor (Ingersoll Rand, Model P375WJD). The supply hose carrying air to the respirator from the compressor contained a $\mathrm{CO}$ alarm (Enmet Corp., Ann Arbor, MI, Model ISA 34 RAL). The blaster's helper wore steel-toed shoes, painter's pants, a Tshirt and a head cloth.

\section{Control Technology}

A temporary canvas enclosure had been erected surrounding areas of the tank being blasted, primarily to keep settled particles confined for easier cleanup. See Figure 2. An exhaust blower (Abatement Technologies, Model \# H 2000 HP) was attached to the enclosure. The exhaust flow rate was nominally $2000 \mathrm{cfm}$. The exhaust was directed through a filter before release to the ambient environment. The main purpose of the blower was to clear the air of dust so the blaster could see well enough to perform his job. Although the air exiting the filter contained no visible dust, frequently large plumes of visible dust were released from gaps in the canvas enclosure during the blasting operations, at times, continuously. 


\section{RESULTS}

\section{Air Sampling}

Personal breathing zone and area air sampling results are summarized in Tables 1 through 3. The analytical method recommends a maximum loading of $2 \mathrm{mg}$ per filter for the cassette and impactor samples. In most cases, the samples for the blaster were well over this limit, and there was loose particulate in the overloaded cassettes and impactor stages.

\section{Wipe Sampling}

Wipe sampling was conducted at five sites, selected for ease of sampling and proximity to the blasting operation; the measured surface concentrations for beryllium are shown in Table 4. A plot of the surface concentrations for 19 metals is shown in Figure 3.

\section{Bulk Sampling}

Two bulk samples of the fresh abrasive were taken, and one sample of the spent abrasive. Results of metals analysis for these bulk samples are given in Figure 4. The concentration of beryllium in the bulk samples was 1.4 and $1.7 \mu \mathrm{g} / \mathrm{g}$. The sample of the spent abrasive had a beryllium concentration of $1.5 \mu \mathrm{g} / \mathrm{g}$. 


\section{CONCLUSIONS AND RECOMMENDATIONS}

Although the percentage of beryllium in the fresh abrasive was relatively low, the blaster exceeded the NIOSH REL and OSHA PEL for beryllium in construction on the first day. He exceeded the OSHA PEL for total dust on both days. The respiratory protection worn by the blaster appeared to provide adequate protection from this potential exposure, based upon the assigned protection factor for that type of respirator. The settled dust near the blasting operation contained a lower surface concentration of beryllium than the maximum permitted by the DOE guidelines. Other guidelines for housekeeping in workplaces that use beryllium are available from several sources. In 1999, OSHA issued a Hazard Information Bulletin, Preventing Adverse Health Effects from Exposure to Beryllium on the Job (OSHA 1999). The following housekeeping steps were among the recommendations in that document.

Employers should ensure that employees use the following safe practices to reduce their exposure to beryllium:

- use high-efficiency particulate air (HEPA) vacuums to clean equipment and the floor around their work areas;

- do not leave a film of dust on the floor after the water dries if a wet mop is used to clean;

- do not use long vacuum hoses and do not loop the hoses that are used;

- never use compressed air to clean parts or working surfaces;

- avoid prolonged skin contact with beryllium particulate; and

- do not allow workers to eat, drink, smoke, or apply cosmetics at their work stations.

The above recommendations apply mostly to indoor abrasive blasting. A more thorough coverage of OSHA regulations covering abrasive blasting in construction is available (29 CFR 1926.57)

Also, when abrasive blasting is performed outdoors, in addition to worker protection considerations, U.S. Environmental Administration (EPA) regulations must be observed. Some guidance for EPA compliance can be found in the documents AP 42, Fifth Edition, Volume I Chapter 13: Miscellaneous Sources, 13.2.6 Abrasive Blasting (EPA 2007) and Emission Factor Documentation for AP-42 Section 13.2.6 (EPA 1997). 


\section{REFERENCES}

10 CFR 850 [2003]. Department of Energy: chronic beryllium disease prevention program.

29 CFR 1910.1000 [2001]. Occupational Safety and Health Administration: air contaminants.

29 CFR 1926.55 [2007]. Occupational Safety and Health Administration: safety and health regulations for construction, occupational health and environmental controls, gases, vapors, fumes, dusts, and mists. Available at

http://www.osha.gov/pls/oshaweb/owadisp.show_document?p table=STANDARDS\&p_id=106 28. Accessed June 26, 2007.

29 CFR 1926.57 [2007]. Occupational Safety and Health Administration: safety and health regulations for construction, occupational health and environmental controls, ventilation. Available at http://www.osha.gov/pls/oshaweb/owadisp.show_document?p table=STANDARDS\&p id=106 31. Accessed June 26, 2007.

42 CFR 85a [2002]. Public Health Service, HHS: occupational safety and health investigations of places of employment.

ACGIH [2001]. Threshold limit values for chemical substances. Cincinnati, OH: American Conference of Governmental Industrial Hygienists.

ASTM [2003]. Standard practice for collection of settled dust samples using wipe sampling methods for subsequent determination of metals. West Conshohocken, PA: American Society for Testing and Materials International, Designation D 6966-03.

ATSDR [2002]. Toxicological profile for beryllium. Atlanta, GA: U.S. Department of Health and Human Services, Public Health Service, Agency for Toxic Substances and Disease Registry.

EPA [1997]. Emission Factor Documentation for AP-42, Section 13.2.6, Abrasive Blasting, Final Report. Research Triangle Park, NC: U. S. Environmental Protection Agency, Office of Air Quality Planning and Standards, Emission Factor and Inventory Group. Available at http://www.epa.gov/ttn/chief/ap42/ch13/bgdocs/b13s02-6.pdf. Accessed June 19, 2007.

EPA [2007]. AP 42, Fifth Edition, Volume I, Chapter 13: Miscellaneous Sources, 13.2.6 Abrasive Blasting. Available at http://www.epa.gov/ttn/chief/ap42/ch13/final/c13s02-6.pdf. Accessed June 19, 2007.

Hornung R, Reed L [1990]. Estimation of average concentration in the presence of nondetectable values. Applied Occupational and Environmental Hygiene, 5(1):46-51. 
Meeker JD, Susi P, Pellegrino A [2006]. Case study: comparison of occupational exposures among painters using three alternative blasting abrasives. Journal of Occupational and Environmental Hygiene 3:D80-D84.

NIOSH [1994]. NIOSH manual of analytical methods. 4th rev. ed., Eller PM, ed. Cincinnati, OH: U.S. Department of Health and Human Services, Public Health Service, Centers for Disease Control and Prevention, National Institute for Occupational Safety and Health, DHHS (NIOSH) Publication No. 94-113.

NIOSH [1997]. NIOSH pocket guide to chemical hazards. Cincinnati, OH: U.S. Department of Health and Human Services, Public Health Service, Centers for Disease Control and Prevention, National Institute for Occupational Safety and Health, DHHS (NIOSH) Publication No. 97-140.

NIOSH [1998] Evaluation of substitute materials for silica sand in abrasive blasting. Contract No. 200-95-2946. Prepared by KTA-Tator, Inc., Pittsburgh, PA. Phase 1:NTIS \# PB99-105553, Phase 2: NTIS \# PB99-140964, Phase 3: NTIS \# PB99-140972. Available at http://www.cdc.gov/niosh/abrpt946.html, accessed June 24, 2004.

OSHA [1999]. OSHA Hazard Information Bulletins: Preventing Adverse Health Effects from Exposure to Beryllium on the Job. Hazard Information Bulletin no. 19990902.

Stettler LE, Donaldson HM, Grant GC [1982] Chemical composition of coal and other mineral slags. American Industrial Hygiene Association Journal, 43:235-238. 
Table 1 -Personal Breathing Zone Total Dust and Beryllium Sampling Results

Cassette Samples, June 22 and 23, 2004

\begin{tabular}{|c|c|c|c|c|c|c|c|c|c|}
\hline \multirow[b]{2}{*}{ Worker } & \multirow{2}{*}{$\begin{array}{l}\text { Total Dust } \\
\text { (mg/ sample) }\end{array}$} & \multirow{2}{*}{$\begin{array}{c}\text { Beryllium } \\
(\mu \mathrm{g} / \text { sample })\end{array}$} & \multirow{2}{*}{$\begin{array}{c}\text { Flow } \\
\text { Rate } \\
\text { (L/min) }\end{array}$} & \multirow{2}{*}{$\begin{array}{c}\text { Sample } \\
\text { Time } \\
\text { (min) }\end{array}$} & \multirow{2}{*}{$\begin{array}{c}\text { Sample } \\
\text { Volume } \\
\left(\mathrm{m}^{3}\right)\end{array}$} & \multicolumn{2}{|c|}{ TWA } & \multicolumn{2}{|c|}{ 8-hr TWA } \\
\hline & & & & & & $\begin{array}{c}\text { Dust } \\
\left(\mathrm{mg} / \mathrm{m}^{3}\right)\end{array}$ & $\begin{array}{c}\mathrm{Be} \\
\left(\mu \mathrm{g} / \mathrm{m}^{3}\right)\end{array}$ & $\begin{array}{c}\text { Dust } \\
\left(\mathrm{mg} / \mathrm{m}^{3}\right)\end{array}$ & $\begin{array}{c}\mathrm{Be} \\
\left(\mu \mathrm{g} / \mathrm{m}^{3}\right)\end{array}$ \\
\hline \multicolumn{10}{|c|}{ Day 1} \\
\hline \multirow{3}{*}{ Blaster } & $120^{\dagger \dagger}$ & 0.38 & 1.04 & 58 & 0.060 & \multirow{3}{*}{1428} & \multirow{3}{*}{5.3} & \multirow{3}{*}{562} & \multirow{3}{*}{2.1} \\
\hline & $69^{\dagger t}$ & 0.29 & 1.04 & 61 & 0.063 & & & & \\
\hline & $91^{t+}$ & 0.37 & 1.04 & 70 & 0.073 & & & & \\
\hline Helper & 0.25 & $(0.005)$ & 1.02 & 196 & 0.200 & 1.25 & $(0.03)$ & 0.51 & $(0.01)$ \\
\hline \multicolumn{10}{|c|}{ Day 2} \\
\hline \multirow{3}{*}{ Blaster } & $6.3^{\dagger}$ & $(0.006)$ & 1.02 & 22 & 0.022 & \multirow{3}{*}{274} & \multirow{3}{*}{0.22} & \multirow{3}{*}{35.4} & \multirow{3}{*}{0.029} \\
\hline & $10^{\dagger t}$ & 0.025 & 1.02 & 28 & 0.028 & & & & \\
\hline & 1 & $(0.005)$ & 1.02 & 12 & 0.012 & & & & \\
\hline Helper & {$[0.014]$} & {$[0.004]$} & 1.06 & 75 & 0.080 & {$[0.18]$} & {$[0.04]$} & {$[0.03]$} & {$[0.01]$} \\
\hline
\end{tabular}

Numbers in parentheses indicate a semi-quantitative value between the limit of detection (LOD) of $0.005 \mu \mathrm{g}$ of beryllium per sample and the limit of quantitation (LOQ) of $0.02 \mu \mathrm{g}$ of beryllium per sample. The LOD for total dust was $0.02 \mathrm{mg}$ per sample. Numbers in brackets were less than the LOD; a value of the LOD/sqrt2 was substituted.

$\dagger$ These samples exceeded the maximum method-recommended sample loading of $2 \mathrm{mg}$, and had loose particles in the cassette, whose weight is included in the above-reported value.

$\$$ These samples had stained backup pads, so the reported weight may be less than actually sampled. 
Table 2 - Total Dust and Beryllium Area Sampling Results-Cassette Samples.

\begin{tabular}{|c|c|c|c|c|c|c|c|c|c|}
\hline \multirow[b]{2}{*}{ Area } & \multirow{2}{*}{$\begin{array}{l}\text { Total Dust } \\
\text { (mg/ sample) }\end{array}$} & \multirow{2}{*}{$\begin{array}{c}\text { Beryllium } \\
(\mu \mathrm{g} / \text { sample })\end{array}$} & \multirow{2}{*}{$\begin{array}{c}\text { Flow } \\
\text { Rate } \\
\text { (L/min) }\end{array}$} & \multirow{2}{*}{$\begin{array}{c}\text { Sample } \\
\text { Time } \\
\text { (min) }\end{array}$} & \multirow{2}{*}{$\begin{array}{c}\text { Sample } \\
\text { Volume } \\
\left(\mathrm{m}^{3}\right)\end{array}$} & \multicolumn{2}{|c|}{ TWA } & \multicolumn{2}{|c|}{ 8-hr TWA } \\
\hline & & & & & & $\begin{array}{c}\text { Dust } \\
\left(\mathrm{mg} / \mathrm{m}^{3}\right)\end{array}$ & $\begin{array}{c}\mathrm{Be} \\
\left(\mu \mathrm{g} / \mathrm{m}^{3}\right)\end{array}$ & $\begin{array}{c}\text { Dust } \\
\left(\mathrm{mg} / \mathrm{m}^{3}\right)\end{array}$ & $\begin{array}{c}\mathrm{Be} \\
\left(\mu \mathrm{g} / \mathrm{m}^{3}\right)\end{array}$ \\
\hline \multicolumn{10}{|c|}{ Day 1} \\
\hline $\begin{array}{l}\text { Pipe } \\
\text { Stack }\end{array}$ & 0.079 & [0.004] & 1.05 & 126 & 0.13 & 0.59 & {$[0.03]$} & 0.16 & {$[0.01]$} \\
\hline $\begin{array}{l}\text { Inside } \\
\text { Tarp }\end{array}$ & $34^{\dagger}$ & 0.074 & 1.04 & 53 & 0.055 & 615 & 1.3 & 67.9 & 0.15 \\
\hline \multicolumn{10}{|c|}{ Day 2} \\
\hline $\begin{array}{l}\text { Inside } \\
\text { Tarp }\end{array}$ & $3.8^{\dagger}$ & $(0.01)$ & 1.03 & 12 & 0.012 & 309 & $(0.81)$ & 7.72 & $(0.02)$ \\
\hline
\end{tabular}

Numbers in parentheses indicate a semi-quantitative value between the limit of detection (LOD) of $0.005 \mu \mathrm{g}$ of beryllium per sample and the limit of quantitation (LOQ) of $0.02 \mu \mathrm{g}$ of beryllium per sample. The LOD for total dust was $0.02 \mathrm{mg}$ per sample. Numbers in brackets were less than the LOD; a value of the LOD/sqrt2 was substituted.

$\dagger$ These samples exceeded the maximum method-recommended sample loading of $2 \mathrm{mg}$, and had loose particles in the cassette, whose weight is included in the above-reported values. The limit of detection for total dust was $0.02 \mathrm{mg}$ per sample. 
Table 3 - Personal Breathing Zone Total Dust and Beryllium Sampling Results - Impactor Samples.

A. Blaster, Day 1.

\begin{tabular}{|c|c|c|}
\hline $\begin{array}{c}\text { Flow Rate, } \\
\text { liters/min }\end{array}$ & $\begin{array}{c}\text { Sample Time, } \\
\text { minutes }\end{array}$ & $\begin{array}{c}\text { Sample Volume, } \\
\text { liters }\end{array}$ \\
\hline 8.70 & 132 & 1148 \\
\hline
\end{tabular}

\begin{tabular}{|c|c|c|c|c|}
\hline Stage & $\begin{array}{c}\text { Total Dust, } \\
\mathrm{mg}\end{array}$ & $\begin{array}{c}\text { Dust Conc., } \\
\mathrm{mg} / \mathrm{m}^{3}\end{array}$ & $\begin{array}{c}\text { Beryllium, } \\
\mu \mathrm{g}\end{array}$ & $\begin{array}{c}\text { Be Conc., } \\
\mu \mathrm{g} / \mathrm{m}^{3}\end{array}$ \\
\hline 1 & $58 \dagger$ & 51 & 0.22 & 0.19 \\
\hline 2 & $29 \dagger$ & 25 & 0.035 & 0.030 \\
\hline 3 & $5.9 \dagger$ & 5.1 & 0.01 & 0.009 \\
\hline 4 & $0.92 \dagger$ & 0.80 & $\mathrm{ND}$ & -- \\
\hline $\mathrm{BU}$ & $39 \dagger$ & 34 & 0.1 & 0.09 \\
\hline
\end{tabular}

$\dagger$ Loose particulate found in stage included in reported total for stage.

\section{B. Helper, Day 1.}

\begin{tabular}{|c|c|c|}
\hline $\begin{array}{c}\text { Flow Rate, } \\
\text { liters/min }\end{array}$ & $\begin{array}{c}\text { Sample Time, } \\
\text { minutes }\end{array}$ & $\begin{array}{c}\text { Sample Volume, } \\
\text { liters }\end{array}$ \\
\hline 8.60 & 197 & 1694 \\
\hline
\end{tabular}

\begin{tabular}{|c|c|c|c|c|}
\hline Stage & $\begin{array}{c}\text { Total Dust, } \\
\mathrm{mg}\end{array}$ & $\begin{array}{c}\text { Dust Conc., } \\
\mathrm{mg} / \mathrm{m}^{3}\end{array}$ & $\begin{array}{c}\text { Beryllium, } \\
\mu \mathrm{g}\end{array}$ & $\begin{array}{c}\text { Be Conc., } \\
\mathrm{gg}^{3} \mathrm{~m}^{3}\end{array}$ \\
\hline 1 & 0.48 & 0.28 & $\mathrm{ND}$ & -- \\
\hline 2 & 0.2 & 0.1 & $\mathrm{ND}$ & -- \\
\hline 3 & 0.13 & 0.077 & $\mathrm{ND}$ & -- \\
\hline 4 & 0.064 & 0.038 & $\mathrm{ND}$ & -- \\
\hline $\mathrm{BU}$ & 0.19 & 0.11 & $\mathrm{ND}$ & -- \\
\hline
\end{tabular}




\section{Blaster, Day 2.}

\begin{tabular}{|c|c|c|}
\hline $\begin{array}{c}\text { Flow Rate, } \\
\text { liters/min }\end{array}$ & $\begin{array}{c}\text { Sample Time, } \\
\text { minutes }\end{array}$ & $\begin{array}{c}\text { Sample Volume, } \\
\text { liters }\end{array}$ \\
\hline 8.50 & 10 & 85.0 \\
\hline
\end{tabular}

\begin{tabular}{|c|c|c|c|c|}
\hline Stage & $\begin{array}{c}\text { Total Dust, } \\
\mathrm{mg}\end{array}$ & $\begin{array}{c}\text { Dust Conc., } \\
\mathrm{mg} / \mathrm{m}^{3}\end{array}$ & $\begin{array}{c}\text { Beryllium, } \\
\mu \mathrm{g}\end{array}$ & $\begin{array}{c}\text { Be Conc., } \\
\mu \mathrm{g} / \mathrm{m}^{3}\end{array}$ \\
\hline 1 & $18 \dagger$ & 212 & 0.053 & 0.62 \\
\hline 2 & $0.99^{*}$ & 12 & $(0.02)$ & $(0.24)$ \\
\hline 3 & $0.31^{*}$ & 3.6 & $\mathrm{ND}$ & -- \\
\hline 4 & 0.15 & 1.8 & $\mathrm{ND}$ & -- \\
\hline BU & 0.13 & 1.5 & ND & -- \\
\hline
\end{tabular}

$\dagger$ Loose particulate found in stage included in reported total for stage.

*Loose particulate found in stage NOT included in reported total for stage.

Loose particulate mass, not included in total for stage:

Stage 2-6.450 mg; Stage 3-1.596 mg

D. Helper, Day 2.

\begin{tabular}{|c|c|c|}
\hline $\begin{array}{c}\text { Flow Rate, } \\
\text { liters/min }\end{array}$ & $\begin{array}{c}\text { Sample Time, } \\
\text { minutes }\end{array}$ & $\begin{array}{c}\text { Sample Volume, } \\
\text { liters }\end{array}$ \\
\hline 8.57 & 56 & 480 \\
\hline
\end{tabular}

\begin{tabular}{|c|c|c|c|c|}
\hline Stage & $\begin{array}{c}\text { Total Dust, } \\
\mathrm{mg}\end{array}$ & $\begin{array}{c}\text { Dust Conc., } \\
\mathrm{mg} / \mathrm{m}^{3}\end{array}$ & $\begin{array}{c}\text { Beryllium, } \\
\mu \mathrm{g}\end{array}$ & $\begin{array}{c}\text { Be Conc., } \\
\mu \mathrm{g} / \mathrm{m}^{3}\end{array}$ \\
\hline 1 & 0.022 & 0.046 & $\mathrm{ND}$ & -- \\
\hline 2 & $\mathrm{ND}$ & -- & $\mathrm{ND}$ & -- \\
\hline 3 & 0.020 & 0.042 & $(0.01)$ & $(0.02)$ \\
\hline 4 & 0.024 & 0.050 & $\mathrm{ND}$ & -- \\
\hline BU & $\mathrm{ND}$ & -- & $\mathrm{ND}$ & -- \\
\hline
\end{tabular}

ND indicates a result less than the limit of detection, $0.01 \mu \mathrm{g}$ of beryllium per sample.

The limit of quantitation is $0.04 \mu \mathrm{g}$ of beryllium per sample.

BU denotes the backup filter. 
Table 4 - Beryllium Wipe Sample Results

\begin{tabular}{|c|c|l|}
\hline $\begin{array}{c}\text { Site } \\
\text { number }\end{array}$ & $\begin{array}{l}\text { Beryllium, } \\
\mu \mathrm{g} \text { per 100 } \\
\mathrm{cm}^{2}\end{array}$ & \multicolumn{1}{c|}{ Site Description } \\
\hline 1 & 0.074 & Top of plastic pipe stack. \\
\hline 2 & 0.037 & Roof of compressor. \\
\hline 3 & 0.014 & Top of storage box on truck. \\
\hline 4 & 0.047 & Top of plastic tarp covering abrasive stack. \\
\hline 5 & ND & $\begin{array}{l}\text { Top of steel electrical box, opposite side of settling } \\
\text { tank. }\end{array}$ \\
\hline
\end{tabular}

There were also two field blanks (Ghostwipes). No beryllium was detected on the field blanks.

ND indicates a result less than the limit of detection for this method of $0.01 \mu \mathrm{g}$ of beryllium per sample.

The limit of quantitation was $0.03 \mu \mathrm{g}$ of beryllium per sample. 


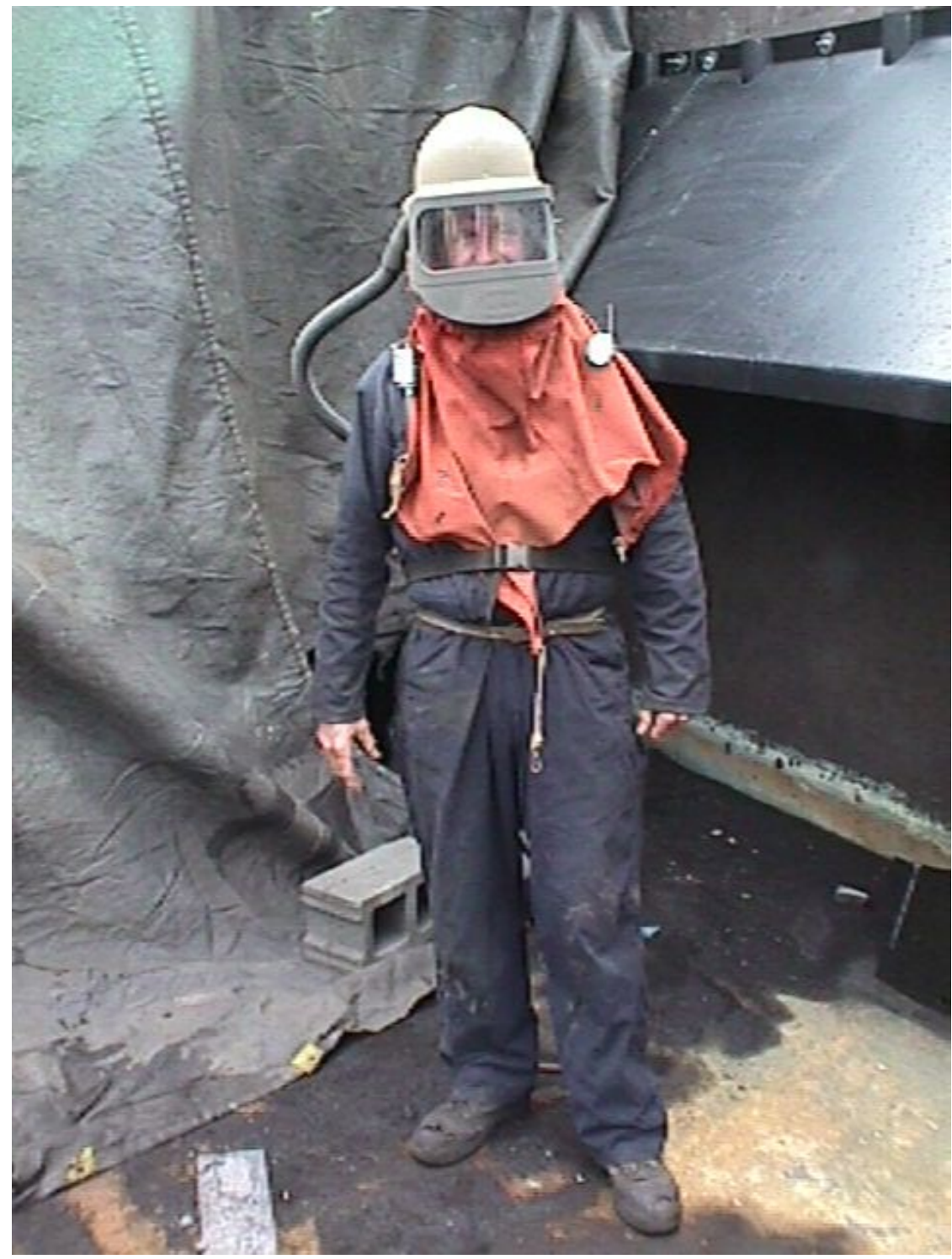

Figure 1. Blaster with personal protective equipment. 


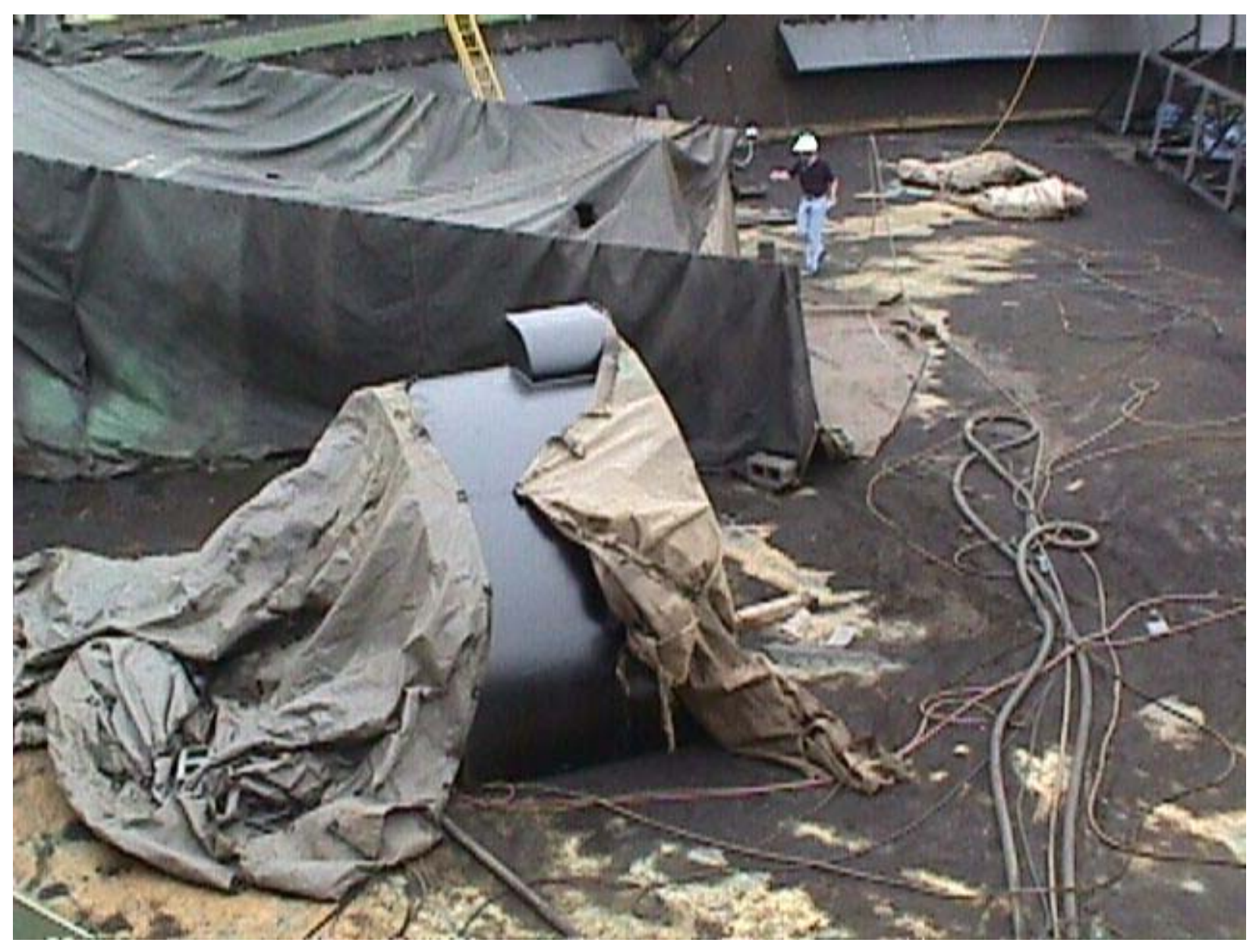

Figure 2. Containment tarps in place for abrasive blasting. 


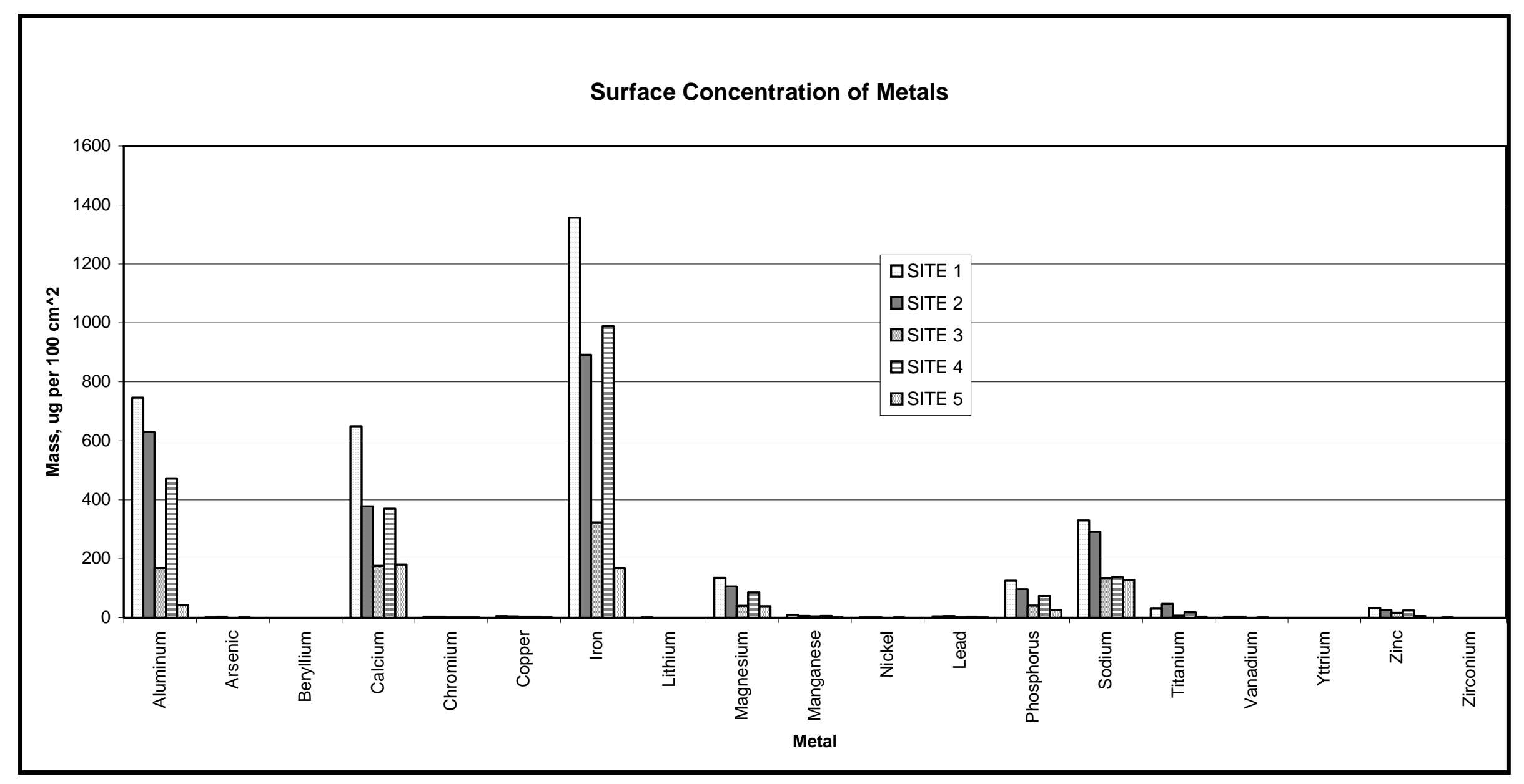

Figure 3. Surface concentration of metals at five sites.

Site 1: Top of plastic pipe stack.

Site 2: Roof of compressor.

Site 3: Top of storage box on truck.

Site 4: Top of plastic tarp covering abrasive bag stack.

Site 5: Top of steel electrical box, opposite side of settling tank. 


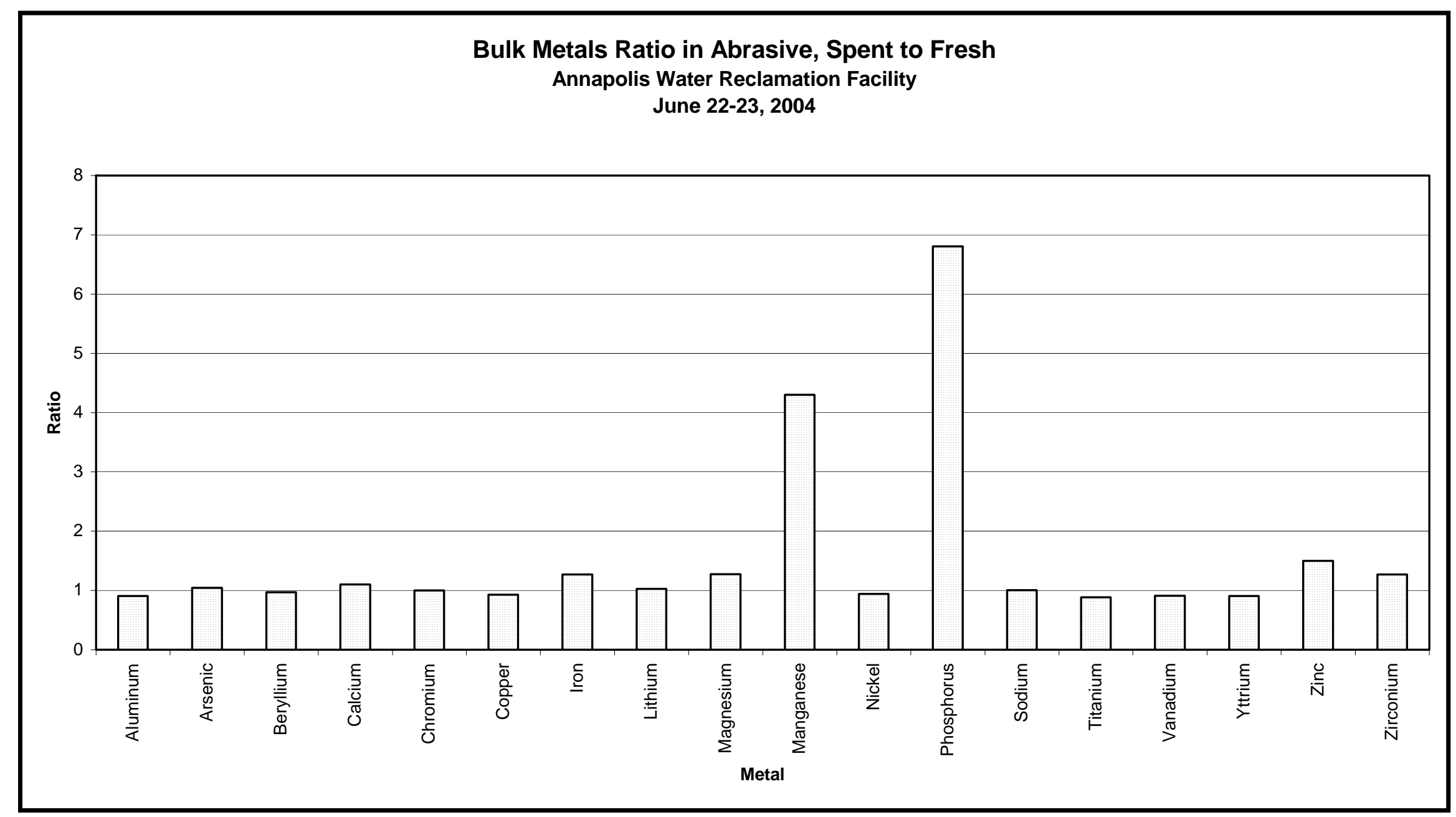

Figure 4. Ratio of metal concentration in bulk spent abrasive to metal concentration in bulk fresh abrasive. 